\title{
Astraea lobata (L.) Klotzsch [Euphorbiaceae]: a new record for Eastern India from Darjeeling Terai
}

\author{
Kishor Biswas ${ }^{1}$ and Chandra Ghosh ${ }^{2}$ \\ ${ }^{1}$ P.G. Department of Botany, Darjeeling Government College, Darjeeling- 734101, West Bengal, India \\ E-mail:kbiswas83@gmail.com \\ ${ }^{2}$ Communicating author: Department of Tea Science, North Bengal University, Darjeeling- \\ 734013, West Bengal, India. E-mail: amichandra07@gmail.com
}

[Received 11.10.2019; Revised 27.11.2019; Accepted 29.11.2019; Published 31.12.2019]

\begin{abstract}
Astraea lobata (L.) Klotzsch [Euphorbiaceae] is recorded for the first time from West Bengal in Eastern India. It occurred in the roadside area of Siliguri subdivision of Darjeeling district. A detailed description with illustration of the species is provided here.
\end{abstract}

Key words: Astraea lobata, New Record, West Bengal

\section{INTRODUCTION}

The genus Astraea, having eight accepted species, is a native of South America and West Indies (www.thelantlist.org, Version 1.12013 ). Astraea lobata (L.) Klotzsch is the only species to be found throughout the Neotropical region and introduced in Africa and Yemen. Though it is native to South America and West Indies, Khan \& Khan (2002) reported this species from Bangladesh. Gaikwad et al. (2012) reported it from Sholapur district of Maharashtra, India for the first time and Das et al. (2016) from Tripura.

During a survey of the road side flora of Darjeeling district, a population of about 12 individuals of Astraea lobata was found near North Bengal University (26 $42^{\prime} 9.83^{\prime \prime} \mathrm{N} \&$ $\left.88^{\circ} 21^{\prime} 05.0^{\prime \prime} \mathrm{E}\right)$ in flowering and fruiting condition. After critical examination and scrutiny of relevant literatures (Chakrabarty \& Balakrishnan 1997; Webster 1993; Govaerts et al. 2000; Khan \& Khan 2002; Balakrishnan \& Chakrabarty 2007; Schmelzer 2007; Gaikwad et al. 2012; Das et al. 2016) the plant was identified as Astraea lobata (L.) Klotzsch. Its occurrence in this locality reports a new distributional record for West Bengal and also for the first time from Eastern India. A detailed description with suitable photographs is provided to facilitate its identification.

\section{TAXONOMIC TREATMENT}

Astraea lobata (L.) Klotzsch, Arch. Naturgesch. (Berlin) 7: 194. 1841; Das et al. Pleione 10(2): 392 - 395. 2016. Croton lobatus L., Sp. Pl. 2: 1005. 1753 “lobatum”; Vell., Fl. Flumin. 10: t. 70. 1831.

Monoecious annual herb, upto $80 \mathrm{~cm}$ high; stem terete, ribbed, branched, stellate-hairy with 1 or 2 branches longer and erect. Leaves simple, alternate; lamina $2.5-11 \mathrm{~cm}$ long, deeply 3 - 5 lobed; lobes oblanceolate to obovate, crenate-serrate with glandular tips, acuminate, 3 5 nerved at base, sparsely stellate-hairy; basal glands present; petioles $2.5-15 \mathrm{~cm}$ long; stipules free lateral, filiform to subulate, c. $1 \mathrm{~mm}$, glandular hairy. Racemes mainly terminal 

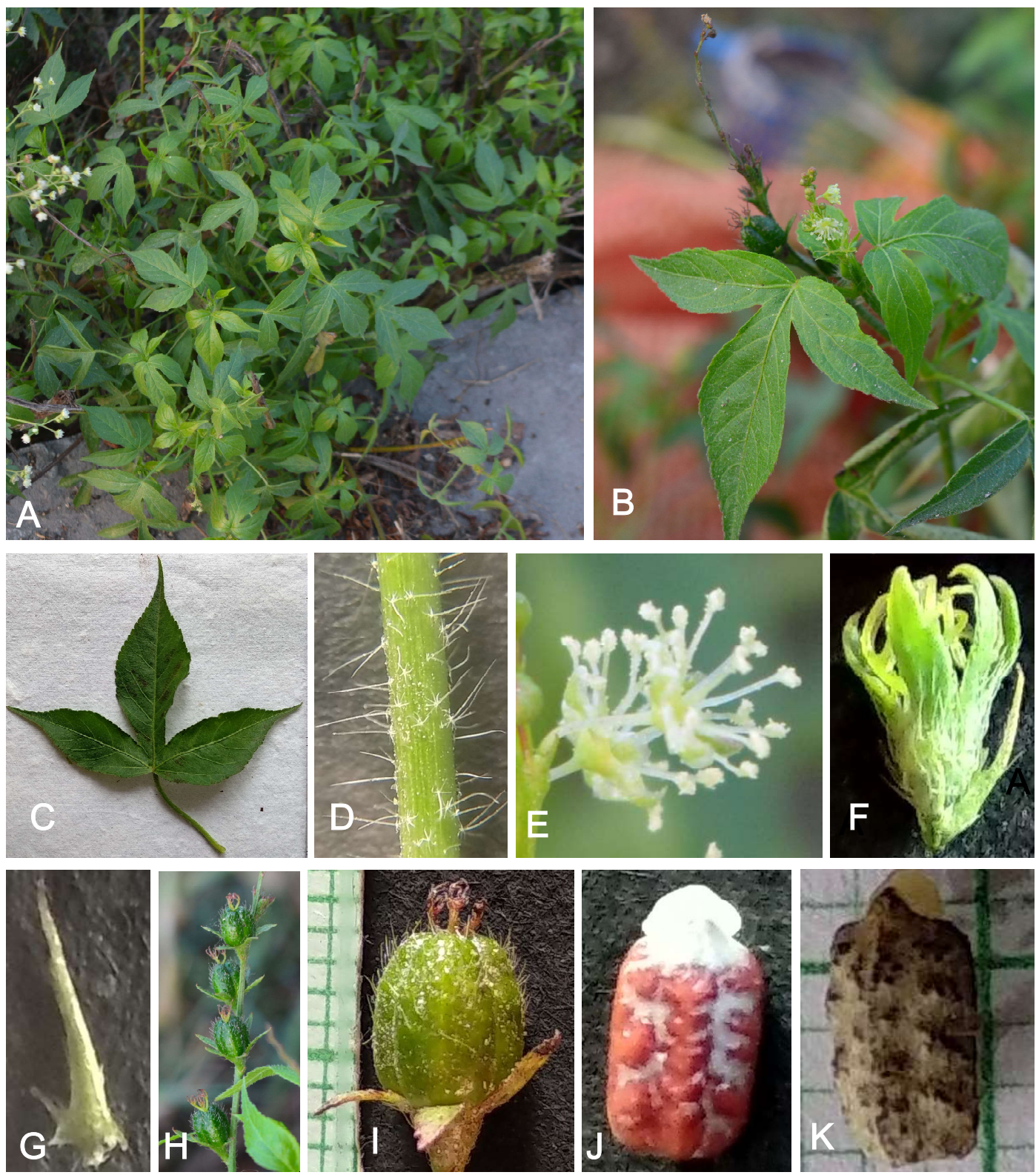

PLATE - I. Astrea lobata (L.) Klotzsch: A. Plant in the habitat; B. Flowering twig; C. Leaf; D. Stellate hair on stem surface with 1 or 2 arms much elongted and staight; E. Male flowers with basal subulate bract; F. Young female flower (opening bud); G. Bract of female flower; H. Infructescence with young fruits; I. Well developed 3-lobed fruit; J. Seed with caruncle; K. Mature seed after dehiscing of fruit.

or axillary, up to $12.5 \mathrm{~cm}$ long, slender; female flowers 4-5 near the base; male flowers in upper half in cymose clusters. Flowers unisexual, 5-merous, regular, yellowish green; Male flowers: Bracts filiform, c. $1 \mathrm{~mm}$, dichlamydeous, buds globose; pedicels slender, $1-2 \mathrm{~mm}$ long; Sepals ovate-elliptic, c. $1 \mathrm{~mm}$ long, obtuse; Petals slightly shorter than sepals, obovateelliptic, obtuse; Stamens $10-13$, basally connate, inflexed in bud; filaments $1-2 \mathrm{~mm}$; anthers $c .0 .5 \mathrm{~mm}$ long, 2-celled, dehisces longitudinally. Female flowers: Bracts c. $1 \mathrm{~mm}$, 
glandular hairy, linear - lanceolate; Pedicels stout, c. $1 \mathrm{~mm}$; monochlamydeous; Bracts of female flowers longer subulate with broader base, for males smaller and subulate; Tepals 5, basally connate, green, persistent; lobes linear-lanceolate, c. $5 \mathrm{~mm}$ long, dentate and glandular, margins hairy; Ovary stellate-hairy, 3-lobed, c.5 mm; styles 3, $2-4 \mathrm{~mm}$ long; each deeply 2 -5 fid, reddish. Capsules ovoid-oblong, $c .7 \mathrm{~mm}$ in diameter, sparsely stellate-hairy, 3-lobed. Seeds 3 , ellipsoid, c. $6 \times 3 \mathrm{~mm}$, roughly 4-ribbed, truncate at base, prominently carunculate, verrucose, ash-coloured with brown spots; carcuncle conical, white.

Flowering \& Fruiting: June - February

Specimens examined: West Bengal, Siliguri, K. Biswas \& C. Ghosh SLG-1217, dated 25.08.2019 (CAL, Lloyd Botanical Garden, DGC Herbarium)

Habitat: Growing on roadsides in low herbaceous vegetation along with Parthenium hysterophorus L., Amaranthus spinosus L., Amaranthus viridis L., Chrysopogon aciculatus (Retz.) Trin., Croton bonplandianus Baill., Sida acuta Burm.f., Cynodon dactylon (L.) Pers., Solanum americanum Mill., Achyranthes bidentata Blume, Tridax procumbens (L.) L., etc.

Distribution: Native of South America and West Indies; introduced in Senegal, Eritrea, Ethiopia, Arabian Peninsula. Bangladesh and India [Maharastra, Tripura (Khan \& Khan 2002; Gaikwad et al. 2012; Das et al. 2016) and now in West Bengal].

\section{LITERATURE CITED}

Balakrishnan, N.P. \& Chakrabarty, T. 2007. The Family Euphorbiaceae in India: A Synopsis of its Profile, Taxonomy and Bibliography. Bishen Singh Mahendra Pal Singh, Dehradun.

Chakrabarty, T. \& Balakrishnan, N.P. 1997. A revision of Croton L. (Euphorbiaceae) for Indian subcontinent. Bull. Bot. Surv. India 34: 1 - 88.

Das Dipti; Kar Somnath \& Datta, B. K. 2016. Extended distribution of Astraea lobata (Linnaeus) Klotzsch [Euphorbiaceae] in India from Tripura. Pleione 10(2): 392 - 395.

Gaikwad, S.P.; Gore, R.D. \& Garad. K.U. 2012. Astraea lobata (Euphorbiaceae), a new record for India. Rheedea. 22(2): $131-132$.

Govaerts, R.; Frodin, D.G. \& Radcliffe-Smith, A. 2000. World Checklist and Bibilogrophy of Euphorbiaceae (and Pandaceae). Vol. 1 - 4. Royal Botanic Gardens, Kew. P. $1-1622$.

Khan, B. \& Khan, M.S. 2002. Taxonomic and distributional notes on the species of Croton L. (Euphorbiaceae) from Bangladesh. Bangladesh J. Pl. Taxon. 9: 77 - 80.

Schmelzer, G.H. 2007. Croton lobatus L. In: Schmelzer, G.H. and A. Gurib-Fakim (Eds.), PROTA (Plant Resources of Tropical Africa), Wageningen, Netherlands.

www.theplantlist.org, Version 1.1, 2013. (studied on 04.09.2019)

Webster, G.L. 1993. A provisional synopsis of the sections of the genus Croton (Euphorbiaceae). Taxon 42: 793 - 823. 